DOI: https://doi.org/10.34069/AI/2020.35.11.6

\title{
Growth of Citrus Fruits in Pakistan
}

\section{Crecimiento de los cítricos en Pakistán}

Received: November 19, 2020

\begin{abstract}
Agriculture is a chief source of economic development and workforce of Pakistan as it contributes 18.5 percent to GDP (Gross Domestic Product), provides 37.4 percent to employment. A well-performing agriculture sector is a key to economic growth but over the decade its performance had been diminutive in Pakistan. Low yield of citrus fruits that is the challenge facing developing countries including Pakistan. The current article identifies information and issues with citrus fruits growth in Pakistan. For the year 2018 area under citrus fruits was 200461 hectares with a production of 2247956 tonnes and yield 112139 hg/hectare in Pakistan. Pakistani farmers are cultivating sweet oranges more than other varieties of citrus fruits. With respect to bordering countries the average yield of Pakistan is more than Afghanistan and less than Iran, China and India. Main constraints to less productivity are: high cost of production, price-instability, and lack of capital, professionalism, technology \& infrastructure. Pets and diseases also causes to less yield. Pakistan can earn foreign exchange more by export of juices rather than export of fresh citrus fruits.
\end{abstract}

Key Words: Citrus-Fruits, Globalization, Growth, Yield, Pakistan.

\section{Introduction}

The economic scenario of the world is going to change, increasing competition and free trade system has integrated the economies of different
Accepted: December 22, 2020

$$
\begin{array}{r}
\text { Written by: } \\
\text { Imran Ahmad Cheema }{ }^{14} \\
\text { https://orcid.org/0000-0003-1076-7283 } \\
\text { Hajan Khan Jamali }{ }^{15} \\
\text { https://orcid.org/0000-0002-8817-2231 }
\end{array}
$$

\section{Resumen}

La agricultura es una fuente principal de desarrollo económico y mano de obra de Pakistán, ya que contribuye con el 18,5 por ciento al PIB (Producto Interno Bruto) y proporciona el 37,4 por ciento al empleo. Un sector agrícola con buen desempeño es clave para el crecimiento económico, pero durante la década su desempeño ha sido escaso en Pakistán. El bajo rendimiento de frutas cítricas es el desafío que enfrentan los países en desarrollo, incluido Pakistán. El artículo actual identifica información y problemas con el crecimiento de los cítricos en Pakistán. Para el año 2018, el área cultivada con cítricos fue 200461 hectáreas con una producción de 2247956 toneladas y un rendimiento de 112139 hg / hectárea en Pakistán. Los agricultores paquistaníes están cultivando naranjas dulces más que otras variedades de frutas cítricas. Con respecto a los países limítrofes, el rendimiento promedio de Pakistán es mayor que Afganistán y menor que Irán, China e India. Las principales limitaciones para una menor productividad son: alto costo de producción, inestabilidad de precios y falta de capital, profesionalismo, tecnología e infraestructura. Las mascotas y las enfermedades también provocan un menor rendimiento. Pakistán puede obtener más divisas mediante la exportación de jugos en lugar de la exportación de frutas cítricas frescas.

Palabras clave: cítricos, globalización, crecimiento, rendimiento, Pakistán.

countries. Increased globalization has deep implications on UDC (under developing countries) economy. Citrus fruits are very

\footnotetext{
${ }^{14} \mathrm{PhD}$ Scholar Department of Economics Preston University Karachi, Pakistan.

${ }^{15}$ Prof. Dr. Member Department of Economics at Preston University Karachi, Pakistan.
} 


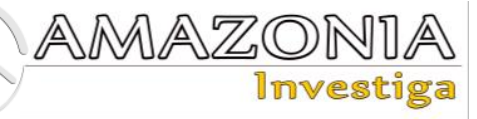

nutritious, offer massive vitamins and minerals that help us to keep healthy. In term of fertile soil and changing climate, Pakistan has suitable natural favors for citrus production. The unique characteristics of citrus fruits produced in Pakistan have made it a valuable commodity.

Although citrus fruits rank first in trade among all fruits produced in Pakistan but the production of citrus fruits is still deficient. Being perishable in nature, it is harvested and consumed in a short period of time. Following are the common varieties of citrus fruits that are grown in Pakistan, which are divided into following groups:

- SWEET-ORANGES: Jaffa-sweet, Mausami, Succri, Ruby-red, Red-blood and Valencia-late.

- MANDARINES: Kinnow, Feutrell-Early, and Nagpuri Sangtra.

- GRAPE FRUITS: Duncan, Mash-Seedless, Foster and Shamber.

- LIME: Key-Lime and Sweet-Lime.

- LEMON: Eureka-Lemon, Lisbon-Lemon, and Rough-Lemon.

\section{Theoretical framework}

In the context of citrus and crops, many studies have been documented. The author reviewed the studies conducted in Pakistan or elsewhere which identified several issues related to citrus fruits; some factors concerning the study are documented.

There are different folklores about the origin of citrus; most researchers believe that it began to appear in the South-East Asia about 4,000 BC and then extended slowly. Due to technology and international trade, the citrus industry globally became more integrated in the $19^{\text {th }}$ century. Most of the citrus fruits varieties mature during the local winter; normally the peak the season is from November to March.

Sajida Taj, Nadeem Akmal, and M Sharif conducted a research on "Financial Viability for Investing in Citrus Cultivation in Punjab Pakistan" concluded that citrus output starts from 5 th years of the stage of development and remains up to 30th year. The study also shows that 20 years is the ideal economic life of citrus orchards, after that there is a diminishing tendency of yield (Sharif, Akmal, \& Taj, 2009).

Samia Ayaz and Zakir Hussain "Impact of institutional credit on production efficiency of farming sector" recommended that loan for the livestock and agricultural should be improved. The provision of credit facilities increases the income of farmers and finally reduces poverty (Ayaz \& Hussain, 2011).

Muhammad Iqbal, Munir Ahmed, and Abbas conducted a study "The impact of institutional credit on agri-production in Pakistan" concluded three main dynamics which add to the agrigrowth are (i) Better use of Agri-inputs (ii) Technological revolution (iii) Techniques adeptness (Iqbal, Ahmad, Abbas, \& Mustafa, 2003).

Raza Ullah, Ali Mirza, Mehboob Elahi, and Hamid Sultan researched "Impact of Microcredit Scheme on Socioeconomic Status of Farmers" in which it was described that microcredit scheme plays a vital role in alleviating poverty. Microcredit significantly increased the income of the borrower (Alam et al., 2014).

Naveed, Ahmed and Ghafur conducted research on "Role of finance in elevation rural poverty". It was found that microcredit system was well helping the poor, serving them to liberate the poverty and improve their standard. (Ahmad et al., 2004).

Burhan Ahmad and Khalid Mustafa (2006) in there study "Forecasting Kinnow Production in Pakistan" observed that an improved output of Kinnow would be available for consumption. They recommended the requirement for taking measures to upsurge the export of Kinnow by refining packaging and adopting the required global criteria (Ahmad, Ghafoor, \& Badar, 2005).

The marketing chain of citrus involves citrus growers, contractors, commission-agents, wholesellers and retailers. 


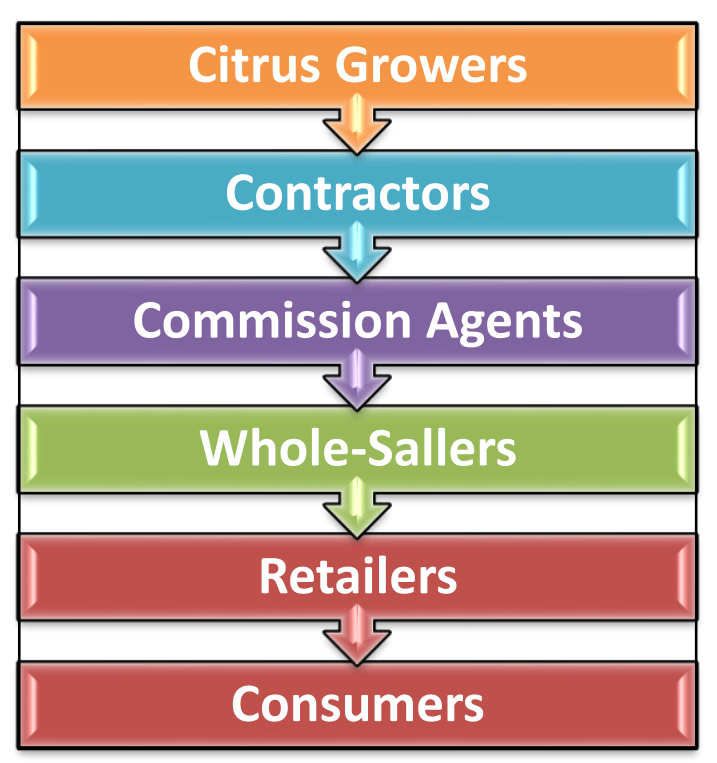

It is a general perception that marketing-agents charge a high margin that exploits producers and consumers. Muhammad Sharif, Umar Farooq, Waqar Malik, and Bashir researched "Citrus Marketing in Punjab Pakistan" in which it was described that growers of citrus orchards are ruined by marketing mediators, Farmer share is only $35 \%$ (Sharif, Farooq, Malik, \& Bashir, 2005).

\section{Methodology}

All the methods/techniques have their own significance and limitations in the researches. According to nature type of the research is descriptive but with respect to data, it is a secondary research. The research hypotheses are the specific statements of prediction which defined what is tried to achieve. It saved time and helped to avoid accumulation of unnecessary data. The current research hypotheses are:

Hypothesis-1: Farmers in Pakistan are cultivating sweet oranges more than other varieties of citrus fruits.

Hypothesis-2: Citrus fruits average yield per hectare of Pakistan is more than bordering countries.
Prominent sources of the data with respect to citrus fruits are:

- FAOSTAT (Food and Agriculture Organization Statistical Data of USA).

- Pakistan Bureau of Statistics.

- Ministry of National Food Security and Research (Pakistan).

Following the principle of neutrality, the study results/conclusions are based on the secondarydata. The data used in the article is derived from FAOSTAT website: http://www.fao.org/faostat/en/\#data.

To achieve desire goal descriptive statistic is considered suitable for data summarizing and analysis. The statistical tools as average, percentage, variance and SPSS are used in the research article. A descriptive research design organized and presented information in a meaningful way. Inferential statistic made the conclusions more general.

\section{Results and discussion}

The production of citrus fruits different varieties in Pakistan from 2001 to 2017 is displayed below: 


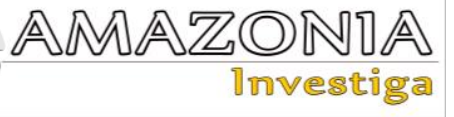

Table 1.

Citrus Varieties Production in Pakistan.

\begin{tabular}{|c|c|c|c|}
\hline \multirow[b]{2}{*}{ Year } & \multicolumn{3}{|c|}{ Citrus Varieties Production (Tonnes) } \\
\hline & Oranges & Mandarins & $\begin{array}{l}\text { Others (Lemons and } \\
\text { Limes) }\end{array}$ \\
\hline 2001 & 1281000 & 476000 & 73000 \\
\hline 2002 & 1190000 & 443000 & 68000 \\
\hline 2003 & 1232000 & 458000 & 70400 \\
\hline 2004 & 1360600 & 505000 & 77700 \\
\hline 2005 & 1721000 & 639000 & 98400 \\
\hline 2006 & 1720867 & 639179 & 98335 \\
\hline 2007 & 1030730 & 382842 & 58899 \\
\hline 2008 & 1606150 & 595670 & 91780 \\
\hline 2009 & 1492400 & 554320 & 85280 \\
\hline 2010 & 1505000 & 559000 & 86000 \\
\hline 2011 & 1387540 & 515372 & 79288 \\
\hline 2012 & 1503140 & 558300 & 86000 \\
\hline 2013 & 1401180 & 520438 & 83782 \\
\hline 2014 & 1517403 & 563607 & 85375 \\
\hline 2015 & 1677340 & 623012 & 83635 \\
\hline 2016 & 1592944 & 592132 & 85060 \\
\hline 2017 & 1585090 & 590752 & 91605 \\
\hline Average & 1459081.4 & 542095.5 & 82502.29 \\
\hline Variety \% & 70.02 & 26.02 & 03.96 \\
\hline \multicolumn{4}{|c|}{ Source: FAOSTAT } \\
\hline
\end{tabular}

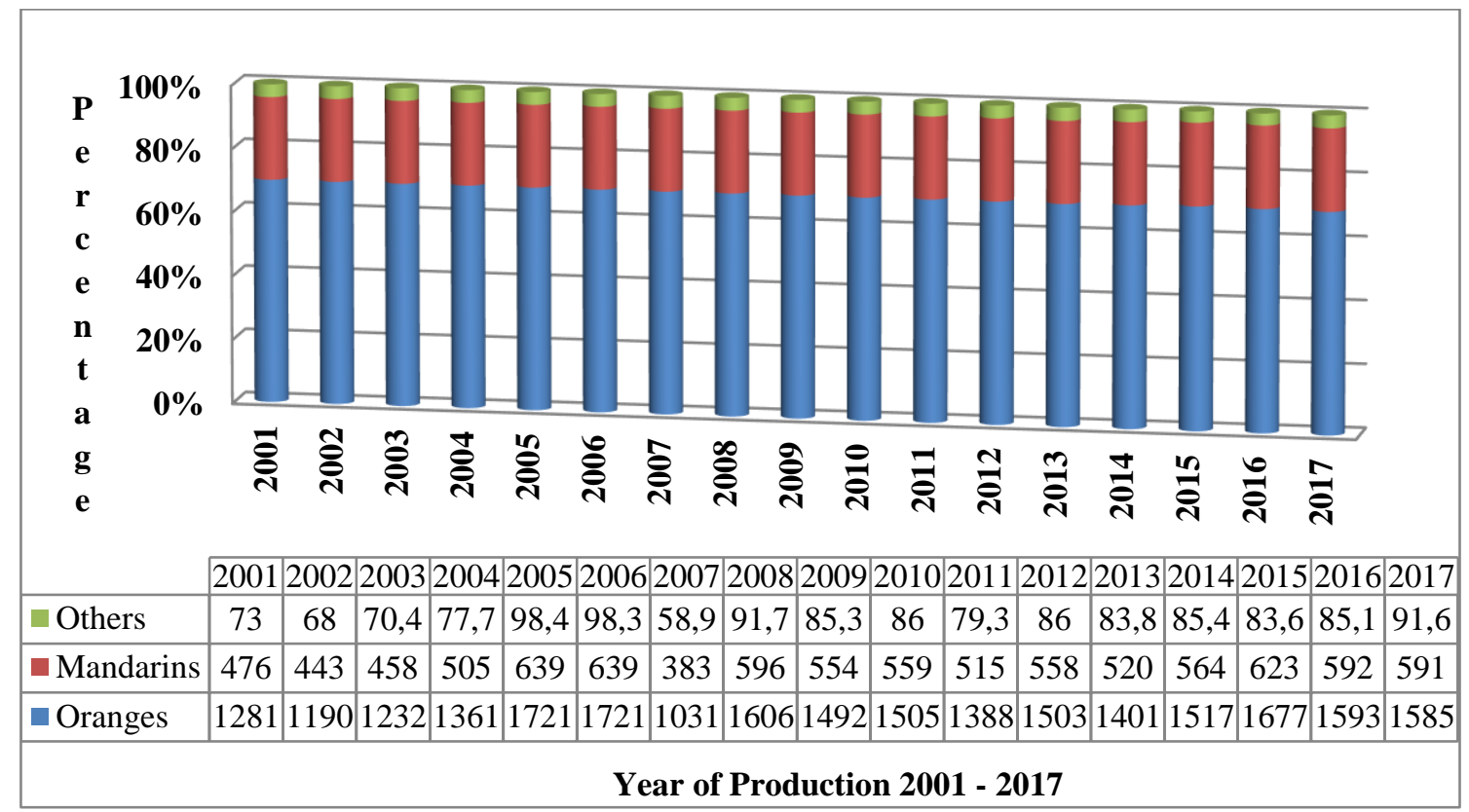

Graph 1. Citrus Fruits Varities Production 'ooo' Tonnes. 
Descriptive Statistics

\begin{tabular}{|l|r|r|r|r|r|}
\hline & \multicolumn{1}{|c|}{$\mathrm{N}$} & \multicolumn{1}{|c|}{ Minimum } & Maximum & \multicolumn{1}{|c|}{ Mean } & Std. Deviation \\
\hline ORANGES & 17 & 1030730 & 1721000 & 1459081 & 194630.358 \\
MANDARINS & 17 & 382842 & 639179 & 542095.53 & 72217.798 \\
LIMES\&LEMONS & 17 & 58899 & 98400 & 82502.29 & 10487.582 \\
Valid N (listwise) & 17 & & & & \\
\hline
\end{tabular}

In Pakistan, agriculture is a chief contributor to GDP either directly or indirectly and significantly contributing to the economy. In respect of citrus varieties structure during the period studied, it is revealed that the production of Orange variety is most. The share of Oranges is $70 \%$, Mandarins is $26 \%$ and other (Lemons + Limes) is $4 \%$ of the total production in Pakistan.

Currently, our citrus industry is in a period of transition. Transition from quantity to quality, low yield to high yield, from fresh fruit to packed juices etc. There is a need to develop early and late maturing varieties so that the supply period can be prolonged. In this regard, high yielding varieties are being imported from foreign countries. It is noted that citrus fruits planting provide a good return to investors than other alternative opportunities available to farmers in Pakistan.

Citrus fruits average yield of Pakistan and bordering countries (India, China, Afghanistan \& Iran) from 2001 to 2017 is presented in the following table:

Table 2.

Citrus fruits average yield of Pakistan.

\begin{tabular}{|c|c|c|c|c|c|}
\hline \multirow{2}{*}{ Year } & \multicolumn{5}{|c|}{ Citrus fruits average yield (hg/hectare) } \\
\hline & Pakistan & India & China & Afghanistan & Iran \\
\hline 2001 & 94184 & 97804 & 89032 & 71909 & 168131 \\
\hline 2002 & 93719 & 90365 & 86674 & 71666 & 174881 \\
\hline 2003 & 99514 & 80302 & 90979 & 73340 & 173257 \\
\hline 2004 & 105499 & 89366 & 93445 & 77966 & 178341 \\
\hline 2005 & 127577 & 97553 & 93381 & 78230 & 183354 \\
\hline 2006 & 127858 & 82072 & 101235 & 68560 & 163811 \\
\hline 2007 & 76211 & 89179 & 102068 & 72575 & 180198 \\
\hline 2008 & 115025 & 92573 & 117424 & 67500 & 156285 \\
\hline 2009 & 106632 & 91825 & 117603 & 50000 & 155849 \\
\hline 2010 & 108367 & 96292 & 120518 & 33333 & 165434 \\
\hline 2011 & 101913 & 98820 & 129599 & 66667 & 172581 \\
\hline 2012 & 110705 & 97136 & 138106 & 66667 & 176929 \\
\hline 2013 & 103379 & 104040 & 149995 & 69037 & 180108 \\
\hline 2014 & 111860 & 109387 & 139280 & 73556 & 176783 \\
\hline 2015 & 123098 & 127943 & 146031 & 61062 & 173419 \\
\hline 2016 & 114705 & 127524 & 146219 & 83199 & 174380 \\
\hline 2017 & 116249 & 120593 & 149840 & 86994 & 216696 \\
\hline \multicolumn{6}{|c|}{ Source:- FAOSTAT (Food and Agriculture Organization Statistical Data) } \\
\hline
\end{tabular}




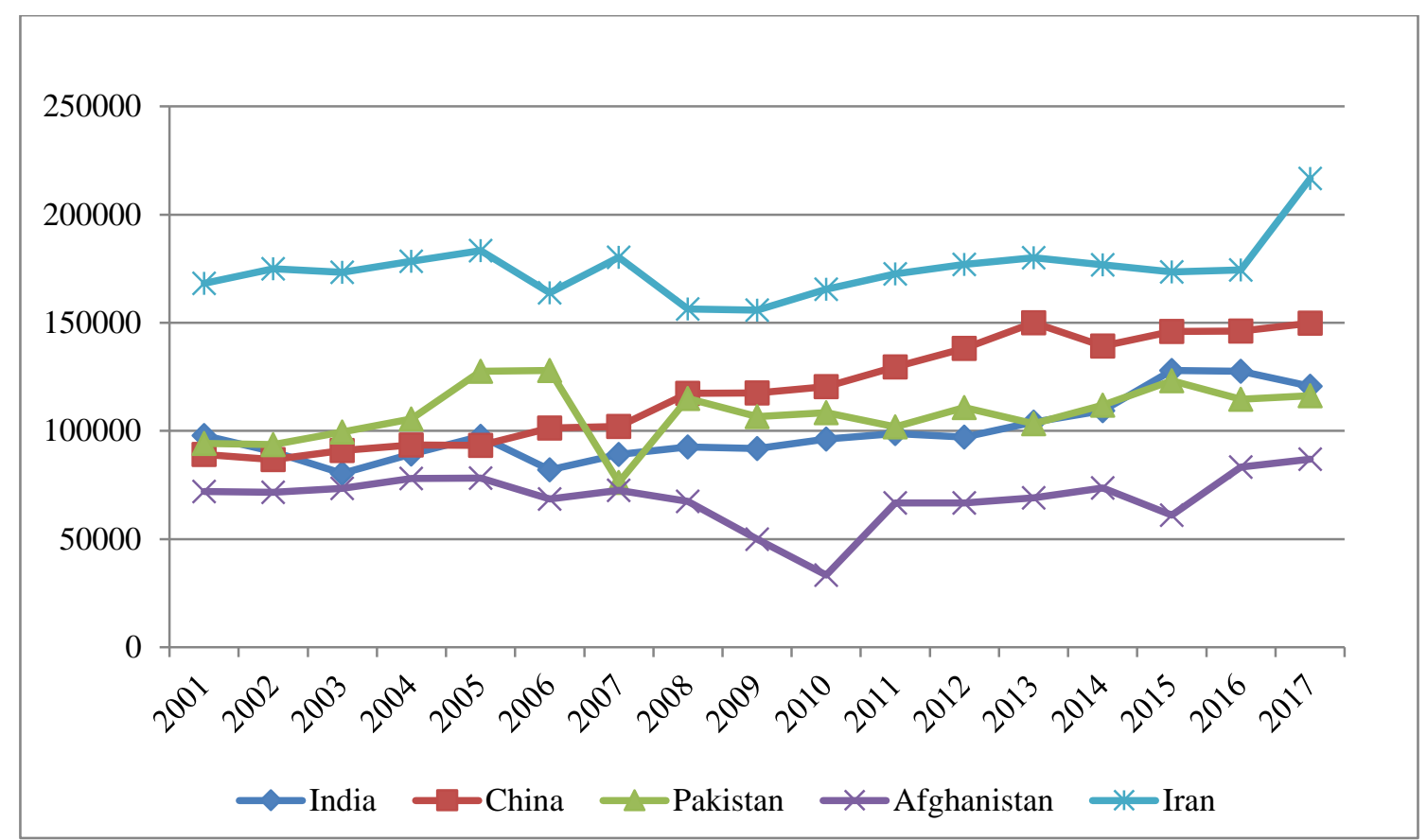

Graph 2. Citrus Fruits Avg Yield of Pkistan and Bordering countries.

During the period 2001-2006 Pakistan's average yield is more than India, China and It is revealed that the citrus fruits average of Iran is most and Afghanistan has the least. Afghanistan. In 2007, there is a decline in Pakistan's yield meanwhile bordering countries have upward trend. By 2015 citrus fruits, the average yield of china, India, and Iran is more than Pakistan.

Citrus fruits growth has many challenges in Pakistan, following are the major constraints:

\section{$>$ Natural Constraints:}

- Pets and diseases

- Natural calamities

- Waterlogging and salinity

$>$ Financial Constraints:

- Price instability

- Scarcity of capital

- Subsistence farming

\section{$>$ Socioeconomic Constraints:}

- Illiteracy

- Scarcity of information

- Lack of professionalism

\section{$>$ Techno-economic Constraints:}

- $\quad$ Low yield varieties
- Improper harvesting

- High production cost

$>$ Post-harvest Constraints:

- Careless handling

- Lack of infrastructure

- Below standard markets

\section{Conclusions}

In the future Pakistan is to be ready for the complete implementation on WTO instructions for opening its market to all members and viceversa. Innovations are necessitated for the growth of the citrus fruits in Pakistan. The government of Pakistan and financial institutions are to reformulate contracts to ease out the loaning process for the alleviation of citrus industry financial constraints. Citrus fruits are to be cultivated in medium density layout after proper leveling with laser technology. High yielding varieties should be planted having less-seeds, salt-tolerant and disease-resistant. Proper frequency of irrigation (either flood or drip irrigation) can plays a vital role in the success of citrus fruits growth.

The ideal amount and timing of fertilization are important to obtain high quality citrus fruit. Pruning should be done to remove dried, diseased and overcrowded branches. Weeds and diseases should be controlled after proper 
consultation of experts. Adopt latest technique and special care for citrus fruits picking, washing, grading, packing, labeling, storage and transportation. Wholesale markets should be reinforced in the production areas. It is the necessity of time to introduce fruit quality certification system. The prominent strategies that can promote citrus fruit growth in Pakistan are as:

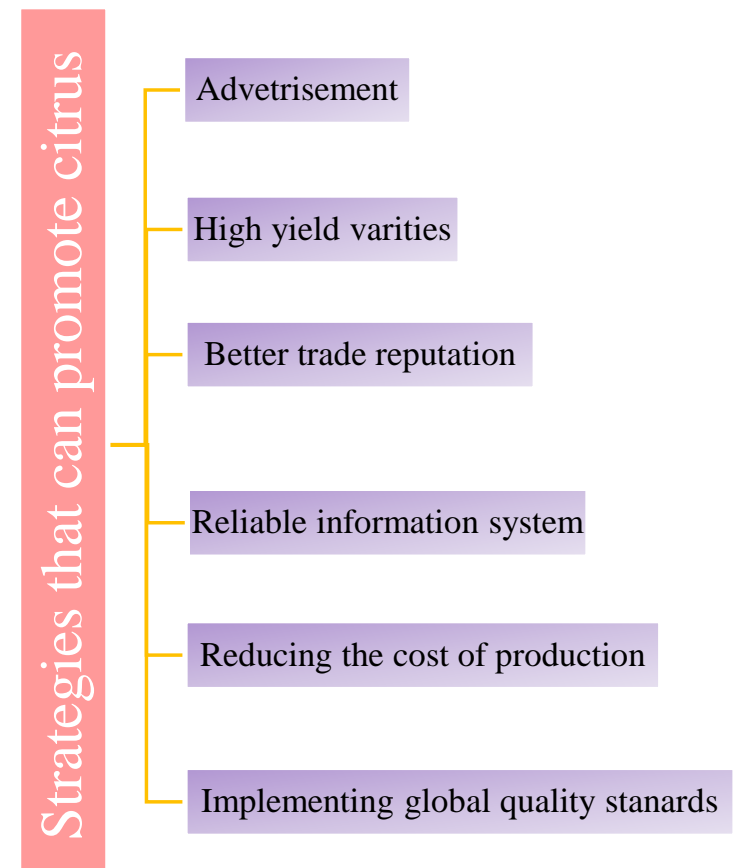

An efficient marketing information service (MIS) (connected with local/international markets and institutions) is essential for the collection and dissemination of information. It will enhance the marketing system efficiency through the provision of timely information that will help to increase citrus growth through remunerative returns to growers and equitable prices to consumers.

\section{Bibliographic references}

Ahmad, B., \& Mustafa, K. (2006). "Forecasting kinnow production in Pakistan: An econometrics analysis". International Journal of Agriculture \& Biology, 8(4), 455-458.

Ahmad, B., Ghafoor, A. \& Badar, H. (2005). "Forecasting and growth trends of production and export of kinnow from Pakistan". Journal of Agriculture \& Social Science, 1, 20-24.

Ahmad, S., Naveed, M. S., \& Ghafoor, A. (2004). "Role of micro finance in alleviating rural poverty: A case study of Khushhali Bank Program in Rahim Yar Khan [Pakistan]". International Journal of Agriculture and Biology (Pakistan).

Alam, M., Ullah, R., Mirza, A. I., Saleem, W., Elahi, M., \& Sultan, H. (2014). "Impact of
Microcredit Scheme on Socio-economic Status of Farmers (A case study of PRSP in District Gujranwala)". South Asian Studies, 29(1), 161. Ayaz, S., \& Hussain, Z. (2011). "Impact of Institutional Credit on Production Efficiency of Farming Sector (A case study of District Faisalabad)". Pakistan Economic and Social Review, 149-162.

Chaudhry, N. A., Maken, M. N., \& Ahmad, M. S. (2004, April). "Native home historical background importance of citrus fruit in Pakistan". In Proc. Int. Conf Citric (pp. 28-30). FAOSTAT.

http://www.fao.org/faostat/en/\#data

Haleem, U., Mushtaq, K., Abbas, A., Sheikh, A. D., \& Farooq, U. (2005). "Estimation of Export Supply Function for Citrus Fruit in Pakistan [with Comments]". The Pakistan Development Review, 659-672.

Iqbal, M., Ahmad, M., Abbas, K., \& Mustafa, K. (2003). "The Impact of Institutional Credit on Agricultural Production in Pakistan". The Pakistan Development Review, 469-485.

Johnson, G. (2006, July). "Pakistan citrus industry challenges: Opportunities for AustraliaPakistan collaboration in research, development and extension". In Pakistan: Citrus Industry Survey and Workshops. 


\section{AMAZOND周 \\ lvvestiga}

Mehdi, M., Ashfaq, M., Hassan, S., \& Abid, M. (2019). "Effect of marketing channel choice on the profitability of citrus farmers: evidence form Punjab-Pakistan". Pakistan Journal of Agricultural Sciences, 56(4).

Rapisarda, P., Calabretta, M. L., Romano, G., \& Intrigliolo, F. (2005). "Nitrogen metabolism components as a tool to discriminate between organic and conventional citrus fruits". Journal of agricultural and food chemistry, 53(7), 2664-2669.

Sharif, M., Akmal, N., \& Taj, S. (2009). "Financial Viability for Investing in Citrus Cultivation in Punjab, Pakistan". Journal of Agricultural Research (Pakistan) 47(1).
Sharif, M., Farooq, U., and Malik, W. (2005). "Citrus Marketing in Punjab." The Pakistan Development Review, 2005. pp 673-694.

Taqarort, N., Echairi, A., Chaussod, R., Nouaim, R., Boubaker, H., Benaoumar, A. A., \& Boudyach, E. (2008). "Screening and identification of epiphytic yeasts with potential for biological control of green mold of citrus fruits". World Journal of Microbiology and Biotechnology, 24(12), 3031-3038.

Usman, M., Ashraf, I., Chaudhary, K. M., \& Talib, U. (2018). "Factors impeding citrus supply chain in Central Punjab, Pakistan". International Journal of Agricultural Extension, 6(1), 01-05. 